Нина С. Милановић*

Универзитет у Источном Сарајеву

Педагошки факултет у Бијељини

https://doi.org/10.18485/ai_petrovic_goran.2020.ch12 821.163.41.09 Петровић Г.

811.163.41'373

\title{
СЕМАНТИЧКО-СТИЛСКЕ ОДЛИКЕ ПРИПОВИЈЕТКЕ ПРИЧА ГОРАНА ПЕТРОВИЋА
}

У раду се бавимо доминантним семантичким и стилским одликама приповијетке Прича Горана Петровића, друкчије речено експресивношћу и структурним ткањем стилских фигура - метафоре, хипотипозе, алегорије и градације. Цијела приповијест сачињена је од низа метафоричких микроелемената (лексема и синтагми) преко реченица до текста као надреченичног јединства, који образују неколико тематских кругова концентрисаних око ликова ове приповијести, а то су усамленички невесели животи

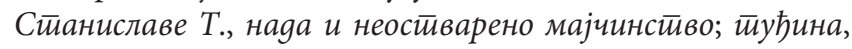
срећа и усйјех, медници Хранислављевог живота, те йрича и ирричане који су у вези са приповједачем и његовом супругом. Метафоричко значење у овој Петровићевој приповијеци прераста микроструктурне елементе, те постаје композиционо начело текста, чиме се цијела Прича преображава у - причу-метафору.

Кључне ријечи: Прича, семантички кругови, метафора, хипотипоза, алегорија, градација, стилогеност, стилематичност.

* ninaceklic@yahoo.com 
Приповијетка Прича ${ }^{1}$ Горана Петровића, објављена у збирци Остирво и околне йриче 1996. године, поред осталих приповиједака из ове збирке, које се баве темама постмодерне поетике, односима стварности и фикције, јаве и сна, колебањем између чудног и чудесног и историје, мотивом приче и снаге ријечи, актуализује и тему нетипичну за рану фазу пишчевог стваралаштва - односно казује о отуђености и усамљености обичног човјека, наднесеног над својим промашеним животом. Ово је семантички двослојна приповијест, метадијагетички задата двјема темама, једној о настајању приче и њеном животу у стварности, и другој о средовјечној, остављеној госпођици Станислави Т., приповједачевој комшиници, коју је извјесни Хранислав, неколико дана уочи вјенчања, напустио, и сада након пуних тридесет година „њених продужених децембара” најавио посјету. Хомодијагетички наратор, у часу када се „управо спремао за једну од својих прича", на молбу несрећне комшинице Станиславе, која жели да види своју велику љубав, „али не и да он види њу, такву каква јесте”, вођен студиозно осмишљеним упутствима своје супруге, „иако није хтио да попусти, све док се није предао" учествује у измишљеној причи Станиславиног живота, у којој је он њен зет, а његова супруга њена кћерка. Приповијест о стварном Станиславином животу, у семантичком смислу, функционише као метафора - у цјелини и појединостима. С друге пак стране, прича о њеном срећном животу представља својеврсно потирање метафоричног значења из кога израста нова метафора. Све што је у пренесеном, аналогном значењу, као ознака припадало њеном

1 (П) у: Горан Петровић, „Прича”, Унуйрашюе gворишӣe, Београд: Лагуна, 2018. 
усамљеничком животу (йаучина на йаваници, скучене

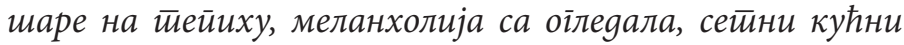
уіллови), у срећној иричи је склоњено, обрисано, сакривено и очишћено. Ријеч је, дакле, о контрапоступку, брисању једне приповијести, преобликовању фикиијске сиивар-

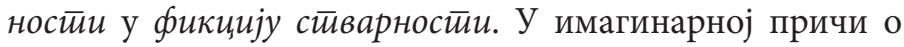
срећном Станиславином животу, поетску метафору као доминантно обиљежје приче о њеном стварном животу парадоксално замјењују слике свакодневнице:

Она не само да је пресложила цео тужан живот Станиславе Т. у ниске радосних дана, већ се побринула да се у њеном стану нађу наше фотографије из младости, а на зиду портрет непостојећег мужа, наводно је Сташа већ пет година била удовица. $(П, 91)$

Метадијагетички токови приповијести смјењују се од приче о тужном животу, која је уједно и стварносна и фикцијска, преко приче о срећном, оствареном животу која са стварношћу није тангента, изузев у актерима као везивним елементима, до разоткривања неистинитости приче, гдје се пројављује њена варљива природа, и на концу, до прихватања стварности, поновно метафорички осликане Станиславиним уздахнутим пребирањем мркосних іромуљица земље у празним глиненим саксијама. И у овој приповијеци, као и у многим другим прозним дјелима, Петровић је оживотворио своју поетичку ноту о судбини приче:

Прича је некада становала на ивици света. Свет је био тепсија обрубљена приповедањем. Касније, када је почео да се шири и заокругљује, свет је халапљиво појео своје ивице, па сада на те остатке можеш да наиђеш готово свуда,чак и у дубокој унутрашњости. 
Имајући у виду Сартрову сентенцу да „човек не постаје писац зато што је одабрао да каже извесне ствари, већ што их је одабрао да их каже на известан начин", а стваралаштво Горана Петровића управо томе и свједочи, у раду ћемо се бавити изражајним средствима, односно стилским фигурама на којима почива стилогеност ове Петровићеве приповијетке, а из досадашњег дијела рада јасно је да је ријеч о метафори и њој блиским фигурама хипотипози, алегорији и градацији. Оне су у приповијеци осложене и другим стилским фигурама - екскламацијом, парцелацијом, ономатопејом, елипсом, кумулацијом, итд. Метафора је фигура настала „преношењем значења по аналогији, по некој сличности", односно утемељена је на „постојању најмање једне заједничке семантичке компоненте између два језичка знака која омогућује везивање означеног једног језичког знака за ознаку другог језичког знака". (Ковачевић 2000: 165) Она се у Причи реализује у три основна семантичка блока концентрисана око ликова ове приповијести - Станиславе Т., Хранислава, те наратора и његове супруге. На самом почетку, именовањем ликова, односно одабиром њихових имена, писац унапријед одређује и њихове судбине. Станислава T. је жена стамена, постојана и непомична, а Хранислав именом својим проноси славу и њоме се води. Она остаје у своме дому, бринући се о тешко покретном оцу и неколико глинених саксија. Хранислав пак одлази у туђину и постаје богат, водећи фирму која тражи срећу и продаје је да би нашла још већу.

Велике теме Станиславиног живота омеђене су цикличним семантичким круговима - невесели усамљенички животи, неостиварено мајчинстиво, наgа. Значењска раван у вези са Хранислављевим животом реализована

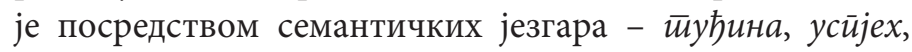
иражене среће, док су ријечи-теме које се односе на наратора-актера и његову супругу - иррича и йричағе. 
Већина наведених синтагми и лексема у приповијеци су посредно исказане метафорама, и то најчешће оним поетским, уско контекстуално условљеним.

Тематски блок невесели усамтенички животи Петровић поетизује сљедећим метафорама:

(1) Била је то пријатна жена, али се сјај у њеним очима задржавао кратко - лепо се видело да је од својих педесетак година имала најмање $\bar{u} p u g e-$ сей са ирродуженим вецембрима. (П, 87);

(2) Моја је жена по тепиху рашчештьла скучене шаре, оілеgало ирребрисала оg вишка меланхолије, да нам буде комотније - расйарила време на gва зияна часовника, а у подрум иренела сейније кућне уілове. Ја сам извршио неке потребне поправке, заменио иум воgе у чесмама, из славине йретиребио ноћно кайане, оястиранио звук

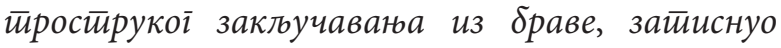

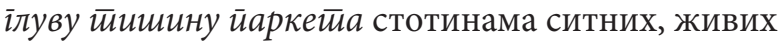
корачаја. (П, 92).

Метафорички израз у првом наведеном примјеру (1) изражен је синтагмом са главним чланом исказаним контекстуалним супстантиватом $\bar{u} p u g e c e \bar{u}$ са ненаведеном, редукованом именицом іоguна. Изостављањем комуникативно редундантне лексеме, већ наведене у микроконтексту, информативно се истиче супстантиват ${ }^{2}$. У овом случају то је број година које је Станислава провела без cjaja у очима. Семантичко жариште метафоре почива на неконгруентном атрибуту исказаном конструкцијом

2 О фигури супстантиватици, новој фигури коју је установио М. Ковачевић, те о њеним структурним типовима и стилогености видјети у раду: М. Ковачевић, „Нова стилска фигура - фигура

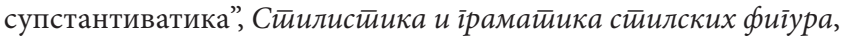
Кантакузин, Крагујевац, 2000. 
са+инструментал - са ирродуженим gецембрима, чијим се декодирањем открива њено денотативно значење, а то је самачки, усамљенички живот. Дакле, дугих тридесет година самоће. О таквим децембрима приповиједа и Андрић у приповијеци Јелена, жена које нема: „Дошли су децембарски дани, они сиви дани пред крај године, кад самци људи отказују позиве за вече и роне све дубље у своју неподношљиву самоћу.”

Друга наведена потврда (2) која припада овом тематском кругу реализована је у форми хипотипозичке метафоре сачињене од низа кумулативних слика, детаља из Станиславиног самачког стана. Кумулативно се нижу хипотипозичке слике чија динамичност и ужурбаност почива на глаголским лексемама рашчешљайu, ире-

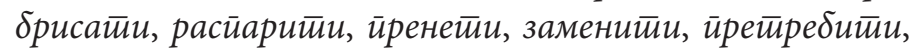

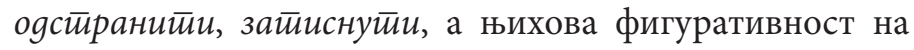
лексемама и синтагмама у функцији објекта. Самачки живот најприје је посредно именован детаљима из Станиславиног стана, из којих зјапи самоћа и учмалост, а потом те устајале, прашњаве ситнице приповједач и његова супруга жустро склањају, бришу и поправљају. Они преслажу тужни живот Станиславе Т. у ниске pagoсних gана. И информативно, и метафоричко жариште су на хомофункционалним мултиплицираним елементима у функцији објекта, а то су синтагме: скучене шаре, оілеgала са вишком меланхолије, сийнији кућни уілови, шум воде у чесмама, звук йростирукоі заклучавана, итд. Њихов заједнички семантички садржалац јесте управо Станиславин усамљенички живот. Цијелу текстну секвенцу могли бисмо подијелити на два дијела - први, у коме нараторова супруга брише прашке меланхолије и сјете, и други у коме приповједач покушава поправити оне веће туге и затиснути их сйойинама, живих сийних корачаја. Овим живим хипотипозичким сликама Петро- 
вић отјелотворује Станиславин тужни живот, који читаоцу постаје опипљив и чујан, препознатљив и стваран.

Семантички оквир неостиварено мајчинсииво поступком майеријализације мейаборе (Мешцерјаков, 2005: 475), који је у теоријским списима о Петровићевом дјелу већ уочен, репрезентује наредни примјер:

(1) Живела је неудавана, готово је цео свој век провела йазећи йешко йокретиноі оца и неколико ілинених йосуgа у којима нишӣа није расло, чак ни случајна йрава. (П, 87);

(2) А шта то она гаји у йим ирразним саксијама у йрозору? (П, 93).

Цијела Петровићева приповијест усидрена је у и око синтагме иразне ілинене йосуge, која се појављује неколико пута у роману. Она је метафора Станиславиног тужног живота, али и њеног неоствареног мајчинства. У тим глиненим посудама је, као и у њој и њеном животу, све пусто и празно. У структурном смислу, овај (3) примјер оформљен је „докидањем уоквирењем” (Шкиљан према Ковачевић 2000: 177), односно елидирањем комуникативно редундантног глаголског прилога $\bar{u} a 3 e \hbar u$ у склопу глаголско-објекатске синтагме, чиме, примарно, ову конструкцију можемо сврстати у елипсу. Међутим, будући да објекатска синтагма неколико ілинених йосуgа има метафоричко значење детерминисано зависном реченицом у којима нишйа није расло, чак ни случајна йрава, те да представља остатке њеног неоствареног живота у коме обитава само она, али и њену тињајућу наду, конструкција је, заправо, зеугмичка, уско контекстуално условљена. Превођењем конотативног значења синтагме йазећи неколико їлинених ӣocyga у основно значење добијамо конструкцију ӣaзећи још неусахлу наgу. Хранислављево зачуђено питање (4) упућено приповје- 
дачу-актеру на крају приповијетке разоткрива причу о причи и објелодањује Станиславин стварни живот. У глиненим саксијама, јунакињином животу, нема радости ни измаштане дјечије граје, нема ничега, посредно поручује Петровић.

Иако лексема наgа ниједном експлицитно није наведена у тексту, изузев на једном мјесту гдје је писац стидљиво преводи у прилог узнаgано, јесте, заправо упориште Станиславиног живота. У приповијеци је актуелизована метафоричким изразом:

(1) Ипак, она их је с пролећа, увек изнова узнаgано износила на балкон. Зими би, да не мрзну, једну до друге, брижно ређала йусте ілинене зделе у окна своі невеселої животиа. (П, 88).

Пети наведени (5) примјера поновно хипотипозички осликава Станиславин невесели живот, али му даје и неку сјетну наду. Стилогеност ове потврде почива на лексеми окна, надређеном члану и метафоричком ријечју у склопу беспредлошке генитивне синтагме. Окна су искре неког сретнијег живота, а у њима су брижно чуване, пусте глинене посуде - нада. Од свих досад ексцерпираних примјера овим се јасно открива суштина метафоре, која се по Блеку разазнаје тек интеракцијом неметафоричког дијела, оквира, са метафоричким фокусом, жаришием (Блек 1986: 55-78). Метафора израња из онеобичајеног споја окна животи $а$.

Туђина, усйјех и йражене среће окоснице су Хранислављевог живота, а Петровић својим онеобичајеним литерарним поступком и поетским метафорама успијева и овдје апстрактне појмове да учини опипљивима, и то управо онако како то А. Ристовић објашњава. Оне „тим лаким фантастичарским исклизнућем добијају и једну додатну симболичну вредност." (Ристовић, 2004: 684) 
(2) Описивао нам је шта је све радио - како је йостииїао несумнив усиех, реч „несумғив" је gвареg йоввккао: како је именован за савеитника Влаgе, реч „влаgа” је изіоворио значајним шайайом; како је йостиао сувтасник јеgне оg йамошних највећих рударских комйанија, реч „највеће” је ӣройрайио ширенем руку. Истина, жена га је напустила, а деца живе далеко од њега. [...] учинило ми се да је у соби од толиких величина постало тесно. (П, 95);

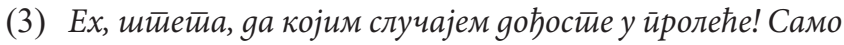

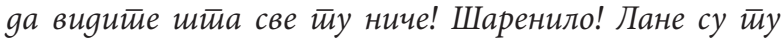
и йииие навраћале! Дивотиа! Па се суние уйлетие! Па иелу ноћ остиане! Каg вам кажем! Не разликујеите дане и ноћи!

Да, да, само наша земља може gа роди нешйо йако чуgесно - промрмљао је гост одсутно. (П, 94);

(4) Туђина је богата срећом, у нас је она реткост - рекао сам, не без одређене зависти.

Можда - колебљиво је потврдио Хранислав. - Али пре свега се морају преврнути огромне количине несреће. Не можете ни замислити та непрегледна брда јаловине. Знате, срећа више није ствар судбине. Морате познавати и имати најсавременију технологију.

Ипак, срећа је срећа. Кад је једном нађете, можете сасвим безбрижно да живите.

Не, млади човече - одговорио је Хранислав. - Када нађемо комадић среће, продајемо га да бисмо могли да наставимо наша испитивања и ископавања. Непрестано улагање је веома важно. (П, 95). 
Стилистичка маркираност наведеног (6) примјера, који припада тематском кругу концентрисаном око семе yсйех, остварена је формом климаксне семантичко-стилистичке градације, и то њеним синтаксичким (под)типом (в. о томе у: Катнић-Бакаршић 1989: 136-142). Додавање најмање једне семантичке компоненте од најмање три елемента у градационом низу „доводи до емотивне обојености цијелог израза” (Ковачевић 2000: 139), што потврђује и овај примјер. У климаксном низу се налазе три реченице - како је йосиииїо несумнив усиеех, како је именован за савеитника Влаgе и како је йостиао сувласник јеgне оg највећих руgарских комӣанија. Климаксној градацији и семантичком степеновању набројаних реченица посебну емфатичност прибављају нараторови коментари који слиједе иза сваке градационе јединице, којима се упућује на информативни фокус и емоционално најистакнутију лексему. У првој реченици градационог низа то је лексема несумнив, gвареg йоgвучена, у другој лексема влаgа, значајним шайайом изіоворена, а у трећој атрибут највећа, иройраћена ширенем руку. Дакле, Хранислављев успјех сачињен је од „великих” ријечи и гестикулације, он је помпезан, али и јалов. Градационом низу у ексцерпираном (6) примјеру опонентна је посљедња реченица којом се обезвређује сав тај бесмислени успјех и изједначава Станиславин и Хранислављев усамљенички живот. Приповједач иронично у наставку запажа да је у просто-

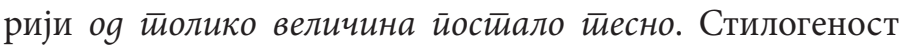
овога примјера почива, дакле, на комбинацији неколико фигура - синтаксичкој градацији, додатно емфатички обојеној приповједачевим „дидаскалијама”, контрасту и иронији.

И наредна (7) потврда у структурном смислу, у појединостима, репрезентује синтаксички подтип семантичко-стилистичке градације осложен екскламацијом, елиптичним реченицама и парцелацијом, док у цјелини 
представља алегорију. Климаксним низањем екскламативних реченица, исцјепканих и сажетих, у приповједачевом одговору на Хранислављево питање шта Станислава гаји у глиненим посудама, постиже се изузетна афективност, емфатичност и експресивност. У покушају да оправда постојање празних глинених посуда у окнима невеселог Станиславиног живота, усхићеност говорникова расте, а машта хиперболично буја до неслућених граница, до птица и сунца уплетеног у прољетно саксијско цвијеће. Врхунац градацијског низа урушава се реченицом која слиједи. Хранислав потврђује да само наша земъа може gа роди нешйо йако чудесно. Његово расположење ишчитава се у ауторској дидаскалији. Он је то одсутно промрмљао. Лексема чуgесно на први поглед уједињује и обједињује све невјероватне побројане слике, али не! Она им се супротставља. Ако су чудесне, онда ликови и читалац „морају прихватити нове законе природе којима би та појава могла бити објашњена" (Тодоров 2010: 42). Исказом наведеним у ауторској дидаскалији та могућност се искључује. Начин на који Хранислав реагује на те „чудесне” призоре урушава, заправо, могућност чудесног и преводи га у алегоријско. Чудесно остаје у домену недосањаног и жељеног, неког другог никад непрежаљеног свијета, али не и проживљеног и могућег. У тренутку када Хранислав и читалац приповједачеве ријечи протумаче као алегорију, чаролија чудесног престаје, а осмишљена прича радосног Станиславиног живота неповратно се распршује.

Оно што одређује Хранислављев живот у туђини

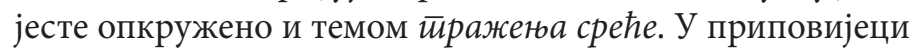
је приказана кратким дијалогом између наратора-актера и Хранислава коју репрезентује посљедња наведена (8) потврда. Differentia specifica овога и претходног примјера почива на потенцијалној неодлучности, односно могућем колебању између чуднога и чудеснога у осмом 
примјеру и прихватања стварности као једине истине у седмом примјеру. Посљедњи (8) ексцерпирани примјер из овог тематског круга уводи елементе фантастичног у приповијест, тако што је могуће да се читалац пита да ли Хранислав заиста тражи срећу у рудницима или је то све алегоријска прича. Уколико би неодлучност читаоца између могућег (објашњивог) и немогућег (необјашњивог) била константна, овај дијалог би ушао у сферу фантастичног. Уколико би пак ову причу читаоци схватили као алегорију, фантастично би престало да постоји. С друге стране, наратор-актер недвојбено учествује у разговору, без имало чуђења. И у једном и у другом случају јасно је да ова прича посредно подражава Хранислављев живот, дакле, оба значења су присутна, а самим тим и неовисна од читаочевог тумачења, што јој по Тодоровљевом провјерном моделу прибавља статус алегорије. „Прво, алегорија подразумева постојање најмање два значења исте речи; у неким случајевима каже нам се да основно значење мора нестати, а у другим да оба морају бити заједно присутна. Друго, то двоструко значење у делу је експлицитно назначено: оно не потиче од читаочевог тумачења, било оно произвољно или не.” (Тодоров 2010: 62) „Мању” срећу, живот са Станиславом, он је замијенио одласком у туђину и непрестаним, халапљивим, прорачунатим тражењем „веће” среће. И у овом примјеру, као и многим другим, Петровић докидањем метафоричког значења, „постваривањем” апстрактних појмова, заправо, гради нову проширену метафору - алегорију, „суперфигуру” (Тодоров 2010: 61), како је још Тодоров назива.

Прича, речи и йричағе, које су у вези са наратором и његово супругом представљају семантички оквир метафоричких израза, што репрезентују примјери:

(5) Пошто је неколико тренутака разілеgала йо сйолу расуйе речи, управо сам се спремао за једну од 
својих прича, Станислава Т. је са два прста опширно размакла капке (...) $(\Pi, 88)$;

(10) Исиоовести наше їошће је шушкала йо сйольаку, више нисам знао шта је моја, а шта њена йрича...(П, 89);

(11) Уздржи се од својих описа, пусти да се живот сам од себе йреирича. (П, 92).

У ексцерпираним примјерима лексеме речи, ӣpuча, ирейричайu представљају покретачке елементе у поступку превођења фикцијске стварности у метафикцијску стварности. Приповијетка Прича тако постаје и прича о настанку приче у којој се преплићу улоге приповједача, аутора и јунака. Хомодијегетички наратор је уједно и аутор приповијести. Чувши Станиславину исйовести која је шушкала йо сииольаку, баш у часу када су

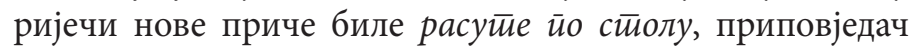
и његова супруга одлучили су да осмисле нову, љепшу причу о комшиничином животу. Наведене лексеме, уско контекстуално условљене, представљају јединствене, ауйорске метафоре животног потенцијала, клице неког новог, можда срећнијег живота. Њихова експресивност и афективност почивају на способности да оживотворе Станиславин уснули и увели живот, јер је прича исто што

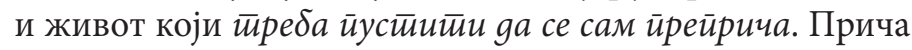
је у Причи, заправо, једина жива. Аналогно томе, оне су примјери непрозирне, поетске метафоре.

Са лингвостилистичког становишта корпус нам је понудио структурне типове метафора остварене у форми зависне синтагме са неконгруентним атрибутима (надређеним чланом као метафоричком лексемом), зависне синтагме са више конгруентних атрибута (поетске метафоре), те у форми реченице и везаног текста (хипотипоза). Метафора је у приповијеци осложена и другим стилским фигурама, зеугмом, ономатопејом, кумулацијом, градацијом (синтаксичком), елипсом, пар- 
целацијом, а понегдје као проширена метафора прераста и у алегорију. Експресивном и емфатичком вриједношћу издвајају се потврде настале комбинацијом више фигура, а међу њима је најистакнутија потврда (7) оформљена градацијским низом екскламативних реченица.

С обзиром на то да се метафоричко значење у Петровићевој приповијеци могло ишчитати искључиво посредно преко ширег смисаоног и реченичног оквира, уско контекстуално условљено, што смо у раду и показали, експресивност Приче почива на, како то Ковачевић истиче „јединој правој метафори”, а то је она поетска, која ствара илузију „приказујући свијет у једном новом свјетлу" (Рикер 1981: 123). А таква је и цијела Петровићева Прича, приповијест о причи-метафори која једина има дар да створи нови свијет у коме из празних глинених саксија, на прољеће изникну младари, сунцем уплетени.

\section{ИЗВОР}

Горан Петровић, „Прича”, Унуйрашюе gворишйе, Београд: Лагуна, 2018.

\section{ЛИТЕРАТУРА}

Блек 1986: M. Blek, „Metafora”, Metafora, figure i značenje, Beograd: Prosveta, 55-78.

Катнић-Бакаршић 1989: M. Katnić-Bakaršić, „Tipovi gradacije”,

Uporabno jezikoslovlje, 136-142, Ljubljana.

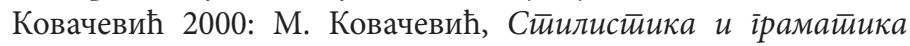
стиилских фиіура, Крагујевац: Кантакузин.

Мешцерјаков 2005: С. Машцерјаков, „Фантастика и реалност у роману Оūcaga иркве Св. Сйаса Горана Петровића” у: Научни сасйанак слависйа у Вукове gане 34/2, Београд: МСЦ, 471-476.

Рикер 1981: P. Ricoeur, Živa metafora, Zagreb: Grafički zavod Hrvatske. 
Ристовић 2004: А. Ристовић, „Ближњи и ближње у прози

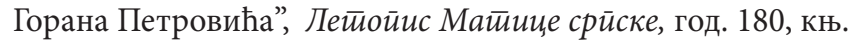
474, св. 5, 680-693, Нови Сад.

Тодоров 2010: C. Todorov, Uvod u fantastičnu književnost, Beograd: Službeni glasnik.

Nina S. Milanović

\section{SEMANTICO-STYLISTIC FEATURES OF THE SHORT STORY “THE STORY” BY GORAN PETROVIĆ}

\section{Summary}

In this paper we have dealt with the expressiveness and structural weaving of the following stylistic figures - metaphor, hypotyposis, allegory and gradation in the story "The Story" by Goran Petrović. The story is made up out of the whole array of metaphorical microelements (lexemes and syntagms) starting all the way from the sentential level to the level of the text as a form of a supra-sentential structure, which form the following thematic circles concentrated around the participants of this story - the lonely and sad life of Stanislava T., hope and unachieeved motherhood; foreign countries, happiness and success, the borderlines of Hranisavljev's life, and finally the story and story-telling that are related to the storyteller and his wife. The metaphorical meaning in Petrovićs story turns into microstructural elements, and becomes the main principle of the composition, turning "The Story" into the story-metaphor. From the linguo-stylistic point of view, the corpus has offered various types of metaphors that appear in the form of a dependent syntagm with both congruent and incongruent attributes (the main element of the syntagm as a metaphorical lexeme), as well as in the form of the sentence and the connected text (hypotyposis, gradation, allegory). The metaphor in this 
story is made complex via the use of other stylistic figures such as zeugma, onomatopoeia, accumulation, gradation (syntactic), ellipsis, parcellation, and, at times, when expanded, the metaphor turns into allegory. The examples that stand out by their expressive and empathic value consist out of a combination of a several figures. The example (7) is the most prominent one and it consists out of a series of exclamatory sentences.

Key words: The Story, semantic circles, metaphor, hypotyposis, allegory, gradation, stylogenity, stylematicity 